\title{
OLIGO-GLUCOMANNAN PRODUCTION FROM PORANG (Amorphophallus oncophyllus) GLUCOMANNAN BY ENZYMATIC HYDROLYSIS USING $\beta$-MANNANASE
}

\author{
Anggela ${ }^{1,2)}$, Widiastuti Setyaningsih ${ }^{1)}$, Santad Wichienchot ${ }^{2)}$, Eni Harmayani ${ }^{1 *}$ \\ ${ }^{1}$ Department of Food and Agricultural Product and Technology, Faculty of Agricultural Technology, Universitas Gadjah Mada, Jalan \\ Flora No. 1, Bulaksumur, Depok, Sleman, Yogyakarta 55281, Indonesia. \\ ${ }^{2}$ Interdisciplinary Graduate School of Neutraceutical and Functional Food, Prince of Songkla University, Hat Yai, Songkhla 90112, \\ Thailand. \\ *) Corresponding author: eniharmayani@ugm.ac.id
}

\begin{abstract}
Porang (Amorphophallus oncophyllus) is an indigenous tuber of Indonesia that rich in glucomannan. An alternative approach to produce porang oligo-glucomannan (POG) as prebiotic from porang glucomannan (PGM) was made by enzymatic hydrolysis using $\beta$-mannanase. This study aimed to produce POG under optimal conditions by controlled enzymatic hydrolysis process. The PGM flour contained $96.12 \%$ of indigestible carbohydrates. The optimum condition of enzymatic hydrolysis producing the highest reducing sugar was as follows: temperature $37^{\circ} \mathrm{C}, \mathrm{pH} 5.5$, a ratio of enzyme to the substrate (E/S) $1: 1000$, and reaction time $4 \mathrm{~h}$. HPLC analysis confirmed that $99.45 \%$ of the resulting POG consisted of oligosaccharides with a degree of polymerization (DP) 3. Hence, the PGM utilized in this study has been proven as a potential substrate for POG production. Additionally, the resulting POG was considered as a functional ingredient due to has prebiotic potential.
\end{abstract}

Keywords: Porang glucomannan, oligo-glucomannan, prebiotic, $\beta$-mannanase, functional ingredient.

\section{INTRODUCTION}

Porang is a parental plant in Indonesia which belongs to the genus Amorphophallus of the Araceae family. Its bulb has glucomannan rich up to $75.72 \%$ in porang flour (Safitri et al., 2014) and $90.98 \%$ in porang tuber (Yanuriati et al., 2017). Although, the high yield of glucomannan is obtained by extraction from dried porang tuber but for industrial scale production prefers extraction from fresh porang tuber due to no drying process is needed thus lower cost of production(Yanuriati et al., 2017).

Glucomannan is a polysaccharide consist of $\beta-1,4$ linked D-glucose and D-mannose residue with short branches of $\beta$-1,6-glucosyl units which is attached at the C-3 position of a sugar unit (Lin et al., 2010). The konjac glucomannan (KGM) has been useful in the biological functions such as constipation mitigation, control of blood glucose and cholesterol level, antioxidant, anti-inflammatory, bioadhesive supplements, and medical implants (Behera and Ray, 2016).

However, the glucomannan application is still limit in expand the functionality in order to its high viscosity and molecular weight, those are responsible for low bioavailability (Ojima et al., 2009). Unfavorable characteristics of it for the food field and pharmaceutical industries (Zhang et al., 2005; Hu et al., 2009). Hence, the porang glucomannan needs to be processed prior to the applications by hydrolyzing the polysaccharides into oligosaccharides. The hydrolysis can be performed by a selected method considering reaction conditions, safety and cost (Yan et al., 2018: de Moura et al., 2014). So, PGM needs processing further with hydrolysis process It is selected based on the performance and considering of reaction conditions, safety and cost (de Moura et al., 201; Yan et al., 2018).

The oligosaccharide production allows to expose on large scale using enzymatic hydrolysis. In the literature, enzymatic process is the best option for oligosaccharides production due to its reproducibility (de Moura et al., 2014). According to $\mathrm{Du}$ et al. (2011) oligosaccharides are mostly produced by either the enzymatic hydrolysis or transglycosylation. These method have been applied based on contribution attributes such as a low energy and safe process (Liu et al., 2015). Hence, this study aimed to develop oligo-glucomannan production and its quality through PGM hydrolysis using $\beta$-mannase.

\section{MATERIALS AND METHODS}

\section{Materials}

Porang glucomannan (PGM) flour was supplied by the Faculty of Agricultural Technology, Universitas Gadjah Mada, Yogyakarta, Indonesia. $\beta$-mannanase was purchased from Mianyang Habio Bioengineering Co., Ltd., Sichuan, China. Sodium acetate was obtained from Sigma-Aldrich Co., St. Louis, USA. Sodium hydroxide was obtained from Loba Chemie, Pvt, Ltd., Mumbai, India.

\section{Methods}

Optimization of porang oligo-glucomannan (POG) production

PGM flour $(1 \% \mathrm{w} / \mathrm{v})$ was added into $0.2 \mathrm{M} \mathrm{CH}_{3} \mathrm{COONa}$ (sodium acetate buffer) and then mixed with $\beta$-mannanase. The concentrations of the enzyme to substrate ratio (E/S) were 1:4000, 1:2000, 1:1000 (w/w). The mixture was stirred continuously in an air incubator shaker at various 
$\mathrm{pH}(5.2,5.5$, and 5.8). The temperature was set at 28, 37 or $48^{\circ} \mathrm{C}$ by the air incubator shaker. In PGM incubation was monitored for $12 \mathrm{~h}$ and samples were taken at 2, 4, 6 , and $12 \mathrm{~h}$. The last step, samples were boiled for $10 \mathrm{~min}$ to inactivate the enzyme then centrifuged at $8,000 \mathrm{~g}$ to remove the enzyme.

\section{Proximate analysis}

The effectiveness PGM as main material was analyzed to measure thephysicochemical properties such as moisture, protein, lipid, crude fiber, and ash contents according to the recommended method by AOAC (1995).

\section{Sugar analysis}

Analysis of total sugar was performed according to the phenol-sulphuric acid method proposed by Dubois et al. (1956) with some modifications for the sample preparation. The sample was diluted 10 to 20 times and a solution of $5 \%$ phenol reagent was added. The reducing sugar was analyzed by the DNS method (Miller, 1959). One unit of mannanase was an enzyme that released one $\mu \mathrm{g}$ of mannose equivalent per minute (Dubois et al., 1956; Miller, 1959).

\section{The degree of polymerization analysis}

Analysis of total sugar was conducted based on the phenolsulphuric acid method. The degree of polymerization (DP) was determined by the ratio of total sugars and reducing sugars.

$\mathrm{DP}=$ Total Sugar/ Reducing Sugar

\section{Oligosaccharides analysis}

The sample was diluted to reach concentration within the available calibration curve of the standard reference. Prior to the injection into high-performance size exclusion chromatography (HPSEC; Agilent model 1200 series, CA, USA), the sample was filtered through a $0.22 \mu \mathrm{m}$ syringe filter. The injection volume was $20 \mu \mathrm{l}$. The flow rate of the mobile phase (distilled water) was set at $1 \mathrm{ml} \mathrm{min}^{-1}$. The setting temperature for the RI detector was $30^{\circ} \mathrm{C}$. The acquired data was recorded by Chem Station software (Agilent Technologies) to estimate the concentration of POG that comprised of polymer, oligomer, and monomer fractionations.

\section{Statistical Analysis}

The effect of the studied variables on the PGM hydrolysis was determined by a one-way analysis of variance (ANOVA). The statistical significance level was set to $p<0.05$ for the significances. In the event that the effects were significant, post hoc test was calculated. The data were presented as mean \pm standard deviation (SD).

\section{RESULTS AND DISCUSSIONS}

\section{Proximate analysis}

The proximate analysis of porang glucomannan is reported in Table 1. The result was founded in PGM contained high carbohydrate $(96.12 \%)$ which mainly polysaccharide as claimed glucomannan. It was calculated based on the dry weight of the PGM. According to Harmayani et al. (2014), PGM flour contains glucomannan almost the same around
$92.69 \%$ of glucomannan. Meanwhile, the glucomannan content in porang powder roughly of $75.72 \%$ (Safitri et al., 2014). As a result that PGM was consisted of lipid (2.52 g/100 g \pm 0.10$)$, crude fiber $(0.37 \mathrm{~g} / 100 \mathrm{~g} \pm 0.05)$, protein $(0.33 \mathrm{~g} / 100 \mathrm{~g} \pm 0.08)$, ash $(0.66 \mathrm{~g} / 100 \mathrm{~g} \pm 0.02)$ and water $(8.48 \mathrm{~g} / 100 \mathrm{~g} \pm 0.15)$. As a comparison, the purity of glucomannan of the extracted porang tuber is enhanced to $90.98 \%$ with a low percentage of ash $(0.57 \%)$ and protein $(0.61 \%)$ without starch content (Yanuriati et al., 2017).

Table 1. The chemical composition of porang glucomannan (PGM) flour.

\begin{tabular}{lc}
\hline Composition & $\begin{array}{c}\text { Content } \\
(\mathbf{g} / \mathbf{1 0 0 g}, \mathbf{d b})\end{array}$ \\
\hline Water & $8.48 \pm 0.15$ \\
Ash & $0.66 \pm 0.02$ \\
Lipid & $2.52 \pm 0.10$ \\
Protein & $0.33 \pm 0.08$ \\
Crude fiber & $0.37 \pm 0.05$ \\
Carbohydrate & $96.12 \pm 0.05$ \\
\hline
\end{tabular}

Values are means \pm SD from duplicate analysis

\section{Effect of temperatures on POG production}

The results of the enzymatic hydrolysis of porang glucomannan powder on the different times are shown in Table 2. The temperatures were varied set at $28{ }^{\circ} \mathrm{C}, 37^{\circ} \mathrm{C}$, and $48{ }^{\circ} \mathrm{C}$, while other parameters were fixed at $\mathrm{pH} 5.5$, time of $12 \mathrm{~h}$, and ratio enzyme to substrate 1:2000 (w/v). The result showed oligosaccharides were not obtained within 2 $\mathrm{h}$ incubation at $28^{\circ} \mathrm{C}$ but increasing gradually incubatiom time during 6-12 h. It was contrary to the trend at $37^{\circ} \mathrm{C}$ and $48^{\circ} \mathrm{C}$. However, the depolymerization of PGM at $37^{\circ} \mathrm{C}$ took time very quickly after $2 \mathrm{~h}$ and elevating gradually during incubation time while no producing the oligosaccharide at $48{ }^{\circ} \mathrm{C}$ was observed after $2 \mathrm{~h}$. The oligosaccharides (\%) at $37{ }^{\circ} \mathrm{C}$ showed significantly increased $(p<0.05)$ after $2 \mathrm{~h}$ and kept maintained during $12 \mathrm{~h}$. Oligosaccharides were produced under the prediction of optimum temperature in a short period incubation time compared to one of the treatments described above $\left(48^{\circ} \mathrm{C}\right)$. It was according to Ariestanti, et al. (2018) reported the highest concentration of oligosaccharide production with lower molecular weight was at the condition of $48^{\circ} \mathrm{C}$

Considering the optimum temperature in enzymatic hydrolysis might not allow too high, because it has been affecting on the denaturation of the enzyme. According the literature that the decreased hydrolytic efficiency of $\beta$-mannanase was probably inactivated with increasing time. Consequently, the temperature and time in this study was chosen based on present oligosaccharide in the beginning time with gaining a yield. Moreover, the optimum temperature was chosen at $37^{\circ} \mathrm{C}$. However, another study demonstrated that there are some aspects on influencing $\beta$-mannanase activity such as substrate concentration, the yield product, and inactivating enzyme (Liu et al., 2015). They also reported that oligosaccharides could be produced by enzymatic hydrolysis at room temperature reflected in this study that produced oligosaccharides at $28^{\circ} \mathrm{C}$ but took a long time of incubation. 
Table 2. The oligosaccharides content (\%) at various temperature of POG production analyzed by high performance size exclusion chromatography (HPSEC).

\begin{tabular}{ccccc}
\hline \multirow{2}{*}{ Temperature } & \multicolumn{4}{c}{ Yield (\%) } \\
\cline { 2 - 5 } $28^{\circ} \mathrm{C}$ & Poly- & Higher oligo- & Oligo- & Mono- \\
\cline { 2 - 5 } 2 & $72.82 \pm 0.16^{\mathrm{a}}$ & ND & ND & $27.19 \pm 0.16^{\mathrm{a}}$ \\
4 & $0.27 \pm 0.01^{\mathrm{b}}$ & $74.45 \pm 0.08$ & ND & $25.29 \pm 0.07^{\mathrm{b}}$ \\
6 & $0.36 \pm 0.01^{\mathrm{b}}$ & ND & $75.04 \pm 0.07^{\mathrm{b}}$ & $24.60 \pm 0.07^{\mathrm{c}}$ \\
12 & $0.21 \pm 0.08^{\mathrm{b}}$ & ND & $76.24 \pm 0.15^{\mathrm{a}}$ & $23.56 \pm 0.15^{\mathrm{d}}$ \\
$37^{\circ} \mathrm{C}$ & & & & \\
2 & $0.20 \pm 0.12^{\mathrm{b}}$ & ND & $69.82 \pm 3.99^{\mathrm{ab}}$ & $29.99 \pm 3.87^{\mathrm{ab}}$ \\
4 & $0.47 \pm 0.12^{\mathrm{a}}$ & ND & $74.64 \pm 0.90^{\mathrm{a}}$ & $24.40 \pm 0.07^{\mathrm{ab}}$ \\
6 & $0.27 \pm 0.02^{\mathrm{ab}}$ & ND & $72.60 \pm 1.89^{\mathrm{ab}}$ & $27.14 \pm 1.87^{\mathrm{b}}$ \\
12 & $0.41 \pm 0.01^{\mathrm{ab}}$ & ND & $66.27 \pm 1.33^{\mathrm{b}}$ & $33.32 \pm 1.32^{\mathrm{a}}$ \\
$48^{\circ} \mathrm{C}$ & & & & \\
2 & $1.63 \pm 1.72^{\mathrm{a}}$ & $72.94 \pm 0.68$ & $\mathrm{ND}$ & $25.44 \pm 1.04^{\mathrm{b}}$ \\
4 & $0.08 \pm 0.05^{\mathrm{a}}$ & ND & $67.34 \pm 0.48^{\mathrm{b}}$ & $32.59 \pm 0.43^{\mathrm{a}}$ \\
6 & $0.17 \pm 0.16^{\mathrm{a}}$ & ND & $72.20 \pm 2.29^{\mathrm{a}}$ & $27.64 \pm 2.45^{\mathrm{b}}$ \\
12 & $0.28 \pm 0.01^{\mathrm{a}}$ & ND & $74.17 \pm 0.21^{\mathrm{a}}$ & $25.56 \pm 0.21^{\mathrm{b}}$ \\
\hline
\end{tabular}

Values are means \pm SD from duplicate incubation in $\%$ area, $\mathrm{ND}=$ not detected

Different letters following mean values within the same column indicate significant differences at the $\mathrm{p}<0.05$.

\section{Effect of pH on POG production}

The results of the enzymatic hydrolysis of porang glucomannan on the different $\mathrm{pHs}$ were shown in Table 3. The hydrolysis process was carried out at a $\mathrm{pH}$ of $5.2,5.5$, and 5.8, while other reaction conditions were set as optimum temperature chosen at $37^{\circ} \mathrm{C}$, enzymatic concentration 1:2000 (w/v) for $12 \mathrm{~h}$. In each condition was found oligosaccharide, but whether the $\mathrm{pH}$ was set at 5.5, showing the oligosaccharide in a short incubation time $(2 \mathrm{~h})$. Meanwhile, the opposite trends were observed at 5.2 and 5.8. They showed oligosaccharide production was found after $4 \mathrm{~h}$ and not presence in the beginning of incubation time. Thus, the optimum $\mathrm{pH}$ for the hydrolysis of PGM was 5.5. It was represented the oligosaccharides obtain in a short period and increased significantly $(p<0.05)$ after $2 \mathrm{~h}$. Usually, the activity and stability of $\beta$-mannanase from various bacteria are optimum in acidic $\mathrm{pH}$ range (56). In the term of PGM hydrolysis, the optimum $\mathrm{pH}$ was at 5.5. In hydrolysis, the activity and stability of enzymes are different depending on typical of buffer composition for maintaining $\mathrm{pH}$ in the reaction (Liu et al., 2015). As a result, a pH of 5.5 of acetate buffer was a value reasonably well with literature previously demonstrated by Ariestanti et al. (2018) and favored with the company requirement of enzyme used.

Table 3. The oligosaccharides content (\%) at various pHs of POG production analyzed by high perfomance size exclusion chromatography (HPSEC).

\begin{tabular}{ccccc}
\hline \multirow{2}{*}{$\mathbf{p H}$} & \multicolumn{4}{c}{ Yield (\%) } \\
\cline { 2 - 5 } & Poly- & Higher oligo- & Oligo- & Mono- \\
\hline 5.2 & & & & \\
2 & $0.29 \pm 0.25^{\mathrm{a}}$ & $76.57 \pm 2.79$ & ND & $23.15 \pm 2.55^{\mathrm{b}}$ \\
4 & $0.51 \pm 0.01^{\mathrm{a}}$ & ND & $74.61 \pm 1.29^{\mathrm{a}}$ & $24.89 \pm 1.28^{\mathrm{ab}}$ \\
6 & $0.35 \pm 0.22^{\mathrm{a}}$ & ND & $73.94 \pm 2.76^{\mathrm{a}}$ & $25.72 \pm 2.54^{\mathrm{ab}}$ \\
12 & $0.30 \pm 0.16^{\mathrm{a}}$ & ND & $70.12 \pm 0.40^{\mathrm{a}}$ & $29.59 \pm 0.56^{\mathrm{a}}$ \\
5.5 & & & & \\
2 & $0.20 \pm 0.12^{\mathrm{b}}$ & ND & $69.82 \pm 3.99^{\mathrm{ab}}$ & $29.99 \pm 3.87^{\mathrm{ab}}$ \\
4 & $0.47 \pm 0.12^{\mathrm{a}}$ & ND & $74.64 \pm 0.90^{\mathrm{a}}$ & $24.40 \pm 0.07^{\mathrm{ab}}$ \\
6 & $0.27 \pm 0.02^{\mathrm{ab}}$ & ND & $72.60 \pm 1.89^{\mathrm{ab}}$ & $27.14 \pm 1.87^{\mathrm{b}}$ \\
12 & $0.41 \pm 0.01^{\mathrm{ab}}$ & ND & $66.27 \pm 1.33^{\mathrm{b}}$ & $33.32 \pm 1.32^{\mathrm{a}}$ \\
5.8 & & & & \\
2 & $0.26 \pm 0.05^{\mathrm{ab}}$ & $79.15 \pm 0.12$ & $\mathrm{ND}$ & $20.60 \pm 0.07^{\mathrm{a}}$ \\
4 & $0.13 \pm 0.01^{\mathrm{c}}$ & ND & $84.92 \pm 5.90^{\mathrm{a}}$ & $14.96 \pm 5.91^{\mathrm{a}}$ \\
6 & $0.15 \pm 0.01^{\mathrm{bc}}$ & ND & $81.70 \pm 0.89^{\mathrm{a}}$ & $18.15 \pm 0.91^{\mathrm{a}}$ \\
12 & $0.26 \pm 0.06^{\mathrm{a}}$ & ND & $82.16 \pm 2.57^{\mathrm{a}}$ & $17.59 \pm 2.62^{\mathrm{a}}$ \\
\hline
\end{tabular}

Values are means \pm SD from duplicate incubation in $\%$ area, ND $=$ not detected

Different letters following mean values within the same column indicate significant differences at the $\mathrm{p}<0.05$. 
Effect of the enzyme to substrate (E/S) ratios on POG production

The results of the enzymatic hydrolysis of porang glucomannan with the different enzyme concentrations are shown in Table 4. Enzyme concentrations were set at 1:4000, 1:2000, and 1:1000 (w/v), while other hydrolysis variables were set as the temperature of $37^{\circ} \mathrm{C}$, pH of 5.5 for $12 \mathrm{~h}$ of incubation time. Escalating ratio enzyme to substrate tends to expand in oligosaccharide production (Chen et al., 2013). When E/S was at 1:1000 (w/v), the oligosaccharide was attained after $2 \mathrm{~h}$ and a highly significant $(\mathrm{p}<0.05)$ after $4 \mathrm{~h}$ with a low monosaccharide concentration $(0.46 \%)$, but no further significant increasing. Hence, the optimum ratio enzyme per substrate is $1: 1000(\mathrm{w} / \mathrm{v})$ for 4 $\mathrm{h}$ of incubation. The result showed an additional $\mathrm{E} / \mathrm{S}$ ratio acquiring oligosaccharide production in order to attach substrate properly to gain product Although, the ability of the enzyme could be decreased by diminishing viscosity of substrate concentration addition (Liu, et al. 2015). They suggested that the glucomannan hydrolysis has to prove the amount of glucomannan with enzyme ratio, It relates to the ability of endo $\beta$-mannanase cleaved the $\beta-1,4$ linkages on the whole substrate (Alonso-Sande et al., 2009; Al-Ghazzewi et al., 2012; Jian et al., 2013). In this study resulted in the minor of polysaccharide and monosaccharide as an undesirable compound is not necessary purification processes for eliminating them. Moreover, the result was claimed its optimum ratio enzyme to substrate produced the oligosaccharides as dominant compound comparing with others, consequently the purification should be not an option in POG production.

Table 3. The oligosaccharides content (\%) at various $\mathrm{pHs}$ of POG production analyzed by high perfomance size exclusion chromatography (HPSEC).

\begin{tabular}{ccccc}
\hline \multirow{2}{*}{ E/S ratio } & \multicolumn{4}{c}{ Yield (\%) } \\
\cline { 2 - 5 } & Poly- & Higher oligo- & Oligo- & Mono- \\
\hline $1: 4000$ & & & & \\
2 & $0.43 \pm 0.01^{\mathrm{a}}$ & $69.81 \pm 2.88^{\mathrm{a}}$ & $29.20 \pm 2.96^{\mathrm{b}}$ & $0.57 \pm 0.08^{\mathrm{c}}$ \\
4 & $0.28 \pm 0.04^{\mathrm{b}}$ & $79.79 \pm 6.91^{\mathrm{a}}$ & $19.16 \pm 6.49^{\mathrm{b}}$ & $0.78 \pm 0.38^{\mathrm{c}}$ \\
6 & $0.31 \pm 0.03^{\mathrm{b}}$ & $\mathrm{ND}$ & $90.58 \pm 1.10^{\mathrm{a}}$ & $9.12 \pm 1.07^{\mathrm{b}}$ \\
12 & $0.20 \pm 0.01^{\mathrm{c}}$ & $\mathrm{ND}$ & $81.95 \pm 0.49^{\mathrm{a}}$ & $17.85 \pm 0.49^{\mathrm{a}}$ \\
$1: 2000$ & & & & \\
2 & $0.20 \pm 0.12^{\mathrm{b}}$ & $\mathrm{ND}$ & $69.82 \pm 3.99^{\mathrm{ab}}$ & $29.99 \pm 3.87^{\mathrm{ab}}$ \\
4 & $0.47 \pm 0.12^{\mathrm{a}}$ & $\mathrm{ND}$ & $74.64 \pm 0.90^{\mathrm{a}}$ & $24.40 \pm 0.07^{\mathrm{ab}}$ \\
6 & $0.27 \pm 0.02^{\mathrm{ab}}$ & $\mathrm{ND}$ & $72.60 \pm 1.89^{\mathrm{ab}}$ & $27.14 \pm 1.87^{\mathrm{b}}$ \\
12 & $0.41 \pm 0.01^{\mathrm{ab}}$ & $\mathrm{ND}$ & $66.27 \pm 1.33^{\mathrm{b}}$ & $33.32 \pm 1.32^{\mathrm{a}}$ \\
$1: 1000$ & & & & \\
2 & $0.20 \pm 0.05^{\mathrm{a}}$ & $99.35 \pm 0.02$ & $\mathrm{ND}$ & $0.46 \pm 0.03^{\mathrm{a}}$ \\
4 & $0.17 \pm 0.05^{\mathrm{a}}$ & $\mathrm{ND}$ & $99.45 \pm 0.09^{\mathrm{ab}}$ & $0.39 \pm 0.04^{\mathrm{a}}$ \\
6 & $0.24 \pm 0.11^{\mathrm{a}}$ & $\mathrm{ND}$ & $99.38 \pm 0.04^{\mathrm{b}}$ & $0.39 \pm 0.08^{\mathrm{a}}$ \\
12 & $0.16 \pm 0.03^{\mathrm{a}}$ & ND & $99.75 \pm 0.13^{\mathrm{a}}$ & $0.10 \pm 0.12^{\mathrm{b}}$ \\
\hline
\end{tabular}

Values are means \pm SD from duplicate incubation in $\%$ area, ND $=$ not detected

Different letters following mean values within the same column indicate significant differences at the $\mathrm{p}<0.05$.

\section{Degree polymerization of POG}

In the optimum condition was found the value of total sugar was $9.85 \mathrm{mg} / \mathrm{ml}$, and the amount of reducing sugar was $2.93 \mathrm{mg} / \mathrm{ml}$, so the amount of DP was 3 . The reducing sugar of POG was obtained under optimal conditions $\left(1: 1000\right.$ of $\mathrm{E} / \mathrm{S}, 5.5 \mathrm{pH}$, and $\left.37^{\circ} \mathrm{C}\right)$ is summarized in Figure 1. The amount of reducing sugar shows the ability of mannanase to hydrolyze porang glucomannan (Safitri et al., 2014). Accordingly, Chen et al. (2013) reported that oligosaccharides production is influenced precisely by reducing sugar present.

More recent studies reported that DP of oligosaccharides produced by all kinds of substrates using enzyme mannanase indicated enzyme capability is restrict to only degrading substrate into oligosaccharide such as mannobiose and not further activity to get small compound (Safitri et al., 2014). Notably, Jian et al. (2013) successfully applied the prolonged incubation time in hydrolysis could obtain oligosaccharide of DP 4-5 into DP 2-3. It was the same in porang glucomannan hydrolysis which produced the same degree of polymerization in range of 3-4. According to Zhang et al. (2009) that konjac flour hydrolyzed by mannanase of Bacillus spp. MSJ-5 produces mannooligosaccharides with DP 2-6 and Liu et al. (2015) found that KOG prepared by degrading konjac glucomannan using $\beta$-mannanase is 5.2 of DP, with the small molecule and high antioxidant activity..

So, in the present study indicated that PGM was successfully hydrolyzed by using $\beta$-mannase produced DP of POG with lower chain length than its native which prepared by cabinet drying (DP 9.4) and by freeze-drying (DP 12) (Harmayani et al., 2014). 


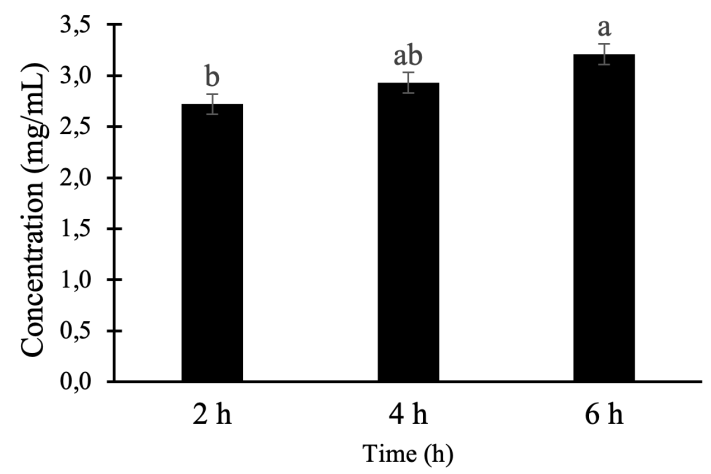

Figure 1. The reducing sugar concentration under optimal conditions $(1: 1000$ or $0.1 \% \mathrm{E} / \mathrm{S}, 5.5 \mathrm{pH}$, and $37 \mathrm{oC})$.

\section{CONCLUSION}

Porang oligo-glucomannan (POG) was successfully produced by controlled hydrolysis conditions of porang glucomannan (PGM) under optimal conditions. The optimal conditions were $37^{\circ} \mathrm{C}, \mathrm{pH} 5.5, \mathrm{E} / \mathrm{S}$ of $1: 1000$ or $0.1 \%(\mathrm{w} / \mathrm{v})$ and reaction time for $4 \mathrm{~h}$. The POG was yielded of $94.45 \%$ with minor contents of polysaccharides and monosaccharides mixture. The majority of POG had DP in the range of 3-4. The results of this study suggested of POG to be applied as prebiotic ingredients in the food industry, due to it is practical for industrial-scale production with high productivity and low cost of production without a purification step. We believe that knowledge gained from this study will help to exploit further and improve the utilization value of porang glucomannan and provide theoretical support for the development of health food in the human study further.

\section{ACIKNOWLEDGMENT}

This work was supported under the master dual degree program both of Gadjah Mada University and Prince of Songkla University and research funding from Graduate School, Prince of Songkla University, Thailand.

\section{REFERENCES}

Al-Ghazzewi, F.H., Tester, RF, and Alvani, K. 2012. The symbiotic effects of konjac glucomannan hydrolysates $(\mathrm{GMH})$ and lactobacilli on the growth of Staphylococcus aureus and Salmonella typhimurium. Nutrition and Food Science. 42 : 97-101.

Alonso-Sande, M., Teijeiro-Osorio, D., Remuñán-López, C., and Alonso, M.J. 2009. Glucomannan, a promising polysaccharide for biopharmaceutical purposes. European Journal of Pharmaceutics and Biopharmaceutics. $72: 453-462$.

AOAC. 1995. Official Methods of Analysis. 16th ed. Assoc. Off. Anal. Chem., Arlington, Virginia, USA.

Ariestanti, C.A., Seechamnanturakit, V., Harmayani, E., and Wichienchot, S. 2018. Optimization on production of konjac oligo-glucomannan and their effect on the gut microbiota. Journal of Food Science and Nutrition. 7(1) : 788-796.

Behera, SS and Ray, R.C. 2016. Konjac glucomannan, a promising polysaccharide of Amorphophallus konjac K. Koch in health care. International Journal of Biological Macromolecules. 92 : 942-956.

Chen, J., Liu, D., Shi, B., Wang, H., Cheng, Y., and Zhang, W. 2013. Optimization of hydrolysis conditions for the production of glucomanno-oligosaccharides from konjac using $\beta$-mannanase by response surface methodology. Carbohydrate Polymer. 93 : 81-88.

de Moura, F.A., Macagnan, F.T., and da Silva, L.P. 2014. Oligosaccharide production by hydrolysis of polysaccharides: a review. International Journal Food Science \& Technology. 1-7.
Du, B., Song, Y., Hu, X., Liao, X., Ni, Y., and Li, Q. 2011. Oligosaccharides prepared by acid hydrolysis of polysaccharides from pumpkin (Cucurbita moschata) pulp and their prebiotic activities. International Journal of Food Science and Technology. 46 : 982-987.

Dubois, M., Gilles, K.A., Hamilton, J.K., Rebers, P.A., and Smith, F. 1956. Colorimetric method for determination of sugars and related substances. 28(3) : 350-356.

Harmayani, E., Aprilia V., and Marsono, Y. 2014. Characterization of glucomannan from Amorphophallus oncophyllus and its prebiotic activity in vivo. Carbohydrate Polymer. 112 : 475-479.

Hu, K., Liu, Q., Wang, S., and Ding, K. 2009. New oligosaccharides prepared by acid hydrolysis of the polysaccharides from Nerium indicum Mill and their anti-angiogenesis activities. Carbohydrate Research. 344 : 198-203.

Jian, H.L., Zhu, L.W., Zhang, W.M., Sun, DF, and Jiang, J.X. 2013. Enzymatic production and characterization of manno-oligosaccharides from Gleditsia sinensis galactomannan gum. International Journal of Biologycal Macromolecules. 55 : 282-288.

Laparra, J.M., Tako, E., Glahn, R.P., and Miller, D.D. 2008. Supplemental inulin does not enhance iron bioavailability to Caco-2 cells from milk- or soy-based, probiotic-containing, yogurts but incubation at 37 ${ }^{\circ} \mathrm{C}$ does. Food Chemistry. 109(1) : 122-128.

Lin, X., Wu, Q., Luo, X., Liu, F., Luo, X., and He, P. 2010. Effect of degree of acetylation on thermoplastic and melt rheological properties of acetylated konjac glucomannan. Carbohydrate Polymer. 82 : 167172.

Liu, J., Xu, Q., Zhang, J., Zhou, X., Lyu, F., Zhao, P., and Ding, Y. 2015. Preparation, composition analysis and antioxidant activities of konjac oligo-glucomannan. Carbohydrate Polymer. 130: 398-404.

Miller, G.L. 1959. Use of dinitrosalicylic acid reagent for determination of reducing sugars. Analytical Chemistry. 31(1) : 426-428.

Ojima, R., Makabe, T., Prawitwong, P., Takahashi, R., Takigami, M., and Takigami, S. 2009. Rheological property of hydrolyzed konjac glucomannan. Transactions of the Materials Research Society of Japan. 34(3) : 477-480.

Safitri, A.H., Yopi and Meryandini, A. 2014. Enzymatic hydrolysis of porang by Streptomyces violascens BF 3.10 mannanase for the production of mannooligosaccharides. Journal Poultry Media. 37(3) : 190-197.

Yan, X., Wang, W., Liu, M., and Zhao, Z. 2018. Preparation of oligosaccharides by degradation of polysaccharides from Chinese Jujube and Its Biological Activity. International Journal of Polymer Science. 1-8.

Yanuriati, A., Marseno, D.W., Rochmadi, and Harmayani, E. 2017. Characteristics of glucomannan isolated from fresh tuber of Porang (Amorphophallus muelleri Blume). Carbohydrate Polymer. 156 : 5663.

Zhang, Y., Xie, B., and Gan, X. 2005. Advance in the applications of konjac glucomannan and its derivatives. Carbohydrate Polymers. 60(1) : 27-31.

Zhang, M., Chen, X.L., Zhang, Z.H., Sun, C.Y., Chen, L.L., He, H.L., Zhou, B.C., and Zhang, Y.Z. 2009. Purification and functional characterization of endo- $\beta$-mannanase MAN5 and its application in oligosaccharide production from konjac flour. Application Microbiology Biotechnology. 83: 865-873. 